\title{
Subaltern Debris: Archaeology and Marginalized Communities
}

\author{
Beatriz Marín-Aguilera
}

\begin{abstract}
Archaeologists, like many other scholars in the Social Sciences and Humanities, are particularly concerned with the study of past and present subalterns. Yet the very concept of 'the subaltern' is elusive and rarely theorized in archaeological literature, or it is only mentioned in passing. This article engages with the work of Gramsci and Patricia Hill Collins to map a more comprehensive definition of subalternity, and to develop a methodology to chart the different ways in which subalternity is manifested and reproduced.
\end{abstract}

\section{(Re)locating the subaltern}

This essay is a meditation on the nature of the subaltern in archaeology. As envisioned by Antonio Gramsci and later on by the Subaltern Studies Group (SSG) in India, the word 'subaltern' is just a common noun used to define all subordinated groups, across time and space. This 'invented' concept thus escapes any social, cultural and historical boundaries, which gives the category of the 'subaltern' immense political flexibility - a flexibility often taken as indeterminacy that has hindered its application by archaeologists and social scientists alike, prompting criticism. It is to these deterrents and criticism that I turn in this article by focusing on the conceptual basis of the subaltern literature in archaeology, its problems and possible solutions.

Understood as a marginalized group vis-à-vis power, subalterns have entered the archaeological debate particularly in the fields of ancient Mediterranean archaeology (Delgado Hervás 2010; van Dommelen 2006; 2014; Zuchtriegel 2018), historical archaeology (Battle-Baptiste 2016; Casella 2012; Ferris et al. 2014; Liebmann 2012; Singleton 2009; Spencer-Wood 1994), and in the archaeology of the most recent past (Gnecco \& Ayala 2011; GonzálezRuibal 2014; 2019b; Hansson et al. 2019; McGuire 2006; Pollock \& Bernbeck 2016). This is reflected in the steady flow of publications discussing subalterns from the early 2000s, and especially from the 2010s, in leading Anglo-American journals such as the Journal of Contemporary Past, International Journal of Historical Archaeology, Historical Archaeology, World Archaeology, Journal of Archaeological Method and Theory and Current Anthropology.

The political reasons for the emergence of subaltern studies in archaeology in the last decades, and in the social sciences more widely, are varied and range from the Dalit movements in India and the civil rights campaigns to put an end to racial segregation in the US to the confrontations within the Truth and Reconciliation Commission in South Africa, the women's liberation movements, the Zapatistas and many other global fights for indigenous rights and the work of scholars from the former colonies in Western universities and institutions. More recently, the analysis of subaltern politics/ideas has been revitalized due to the global environmental disaster and the rise of Indigenous counterhegemonic and more sustainable worldviews, the Arab Spring, the Indignados and Occupy movements, Black Lives Matter, and much more. What these events demonstrate is that it has always been the subaltern, i.e. the Dalit, the black, the peasant, the indigenous, the woman, the poor, etc., who has changed her/his political and economic condition by fighting against the establishment at the time. (White) scholarship comes only later, mostly forced—and rightly so!- by subalterns.

Cambridge Archaeological Journal 31:4, 565-580 @ The Author(s), 2021. Published by Cambridge University Press on behalf of the McDonald Institute for Archaeological Research. This is an Open Access article, distributed under the terms of the Creative Commons Attribution-NonCommercial-ShareAlike licence (http://creativecommons.org/licenses/by-nc-sa/4.0/), which permits non-commercial re-use, distribution, and reproduction in any medium, provided the same Creative Commons licence is included and the original work is properly cited. The written permission of Cambridge University Press must be obtained for commercial re-use. 
Yet, as one of the reviewers of this article pointed out, the term 'subaltern' has become in a certain way an abstract academic cul-de-sac, a rather elusive and rarely theorized concept in archaeological literature (see also González-Ruibal 2019b, 104-6). In fact, many analyses of the subaltern-not only in archaeology-have overlooked the heterogeneity of these groups and the existing antagonisms within them. In their homogenizing endeavour, these studies have conflated the peasant proprietor or better-off subaltern with the poor peasant (Brass 2017), or the discrimination of the Western female subject with the double effaced experiences of 'Third World' women (hooks et al. 2004; Mohanty 1991; Spivak 1988). In archaeology, scholars have very often conflated the subaltern with colonized and/or indigenous groups, disregarding the heterogeneity encompassed by the term (cf. Cañete Jiménez \& Vives-Ferrándiz Sánchez 2011; Cuozzo \& Pellegrino 2016; Dietler 2010; Ferris et al. 2014; Gnecco \& Ayala 2011; Kistler \& Mohr 2016; but see González-Ruibal 2019a; Liebmann \& Murphy 2010; Spencer-Wood 2010). They have denied colonial violence by celebrating a peaceful cohabitation of colonist/colonized groups (cf. Antonaccio 2013; Greco \& Mermati 2011; Malkin 2002; but see Delgado Hervás 2010; Zuchtriegel 2018); or they have disproportionally represented indigenous people as vanquishers of European colonial powers-see especially the case of colonial Chile (Boccara 2008; Dillehay 2007; Sauer 2015).

However, subalterns are neither (only) colonized people, nor homogeneous, quite the opposite. The subaltern is an invented concept that no-one has ever claimed. It does not refer to the identity of any known social group, nor is it an ideality shaped by political philosophers-peasant, proletariat, worker, citizen, indigenous, refugee, etc.-and asserted by historical beings for political reasons (Banerjee 2015, $39,42-3)$. In fact, Gramsci stretched his notion of subalterns to a wide range of oppressed groups (1975, 2286): 'Often, subaltern groups are originally of a different race (different religion and different culture) than the dominant groups, and they are often a mixture of different races, as it is the case of the slaves'. He also included peasants, religious groups and proletarians into the subaltern category (Gramsci 1975, 2286). In fact, Gramsci considered as subalterns all those subordinated groups whose political activity was ignored, misrepresented, or were on the margins of dominant discourses (Green 2013), similar to the SSG in India (Arnold 1984; Chaturvedi 2000; Guha 1988a, 35).

Because the category of subalterns is not tied to any particular historical or cultural ideality, it resists instrumentalization and provides political flexibility and better agility to compare oppressed people in exposed living conditions (Banerjee 2015; Hansson et al. 2019). In order to do so, let me first think through a series of questions to frame better the concept of subalterns and its application to archaeology: Is the subaltern a political subject? How do we approach intersective oppressions among subalterns? How can archaeology approach the experience of subalternity?

\section{Are subalterns political subjects?}

One of the most debated issues by Gramsci and the Subaltern Studies scholars alike has been the question of the subaltern as a political subject, i.e. the agency of subalterns, which was very early called into question by Spivak (1988). According to her, subalternity can be defined as a 'position without identity ... where social lines of mobility, being elsewhere, do not permit the formation of a recognisable basis of action' (De Kock \& Spivak 1992, 45-6; Spivak 2005, 476). Further, Spivak contended that certain organized groups such as workers' unions cease to be subalterns because they are organized and can speak against the elite, and therefore, for Spivak, they partake in the hegemonic discourse (De Kock \& Spivak 1992, 46).

Subalternity, as a 'position without identity' in Spivak's definition, draws a space of blockade and impossibility for action difficult to challenge. In fact, Spivak has received strong criticism since her 1988 publication for precluding the subaltern capacity of action (Mani 1998; Parry 2004, 19-28), for reducing the political consciousness of women to a discourse of female sexuality (Gopal 2004, 149-50), for ignoring class agency (Larsen 2001, 58-74), and for having a very narrow definition of who the subalterns are (Green 2002; Hershatter 1993).

In her interpretation, Spivak aligns with other scholars who, when writing about slaves, defined them as 'socially dead' (Patterson 1982). Such a slippage between discourse and social reality elides important geographical and historical specificities. Besides, to see slaves and other unprivileged people as socially dead or as passive and mere victims of colonial and capitalist processes is to take at face value some of the more disgraceful allegations made by colonial officers and slave owners (Burnard \& Heuman 2011; Fanon 1952; Said 1989) and to confirm-ironically enough-the subalternization to which they have been subjected.

Contra Spivak (and Gramsci), Guha and other Subaltern scholars defined the subaltern as an 
agent autonomous from the elite, the State and bourgeois and colonialist ideologies (Guha 1988b,c; Prakash 1994). Similarly, James Scott celebrated the agency of the subalterns against oppressive regimes by focusing on low-profile forms of resistance, such as tax evasion, false compliance, foot-dragging, pilfering, feigned ignorance, dissimulation, defamation and sabotage (Scott 1985; 1990; 2013). Those studies have been caught, to different degrees, in binary questions of dominance and insurgence/resistance and, in other cases, in intellectual discussions on power and knowledge (Chakrabarty 2000; Chatterjee 2010; Sharpe \& Spivak 2003; Spivak 1988; 1990).

Emphasis on rebellion and resistance has also been the norm in archaeology, especially in postcolonial archaeology-something that has been reconsidered recently (Liebmann \& Murphy 2010; Lightfoot 2015). Archaeologists sided with the oppressed subaltern against the elite or the colonial authorities by evidencing mainly uprisings and defiance, among slaves in colonial South Africa (Hall 2000) and nineteenth-century Islamic Zanzibar (Croucher 2015), among indigenous and slaves alike in Portuguese Brazil (Gomes Coelho 2009; Orser \& Funari 2001), among indigenous women on the Spanish Orinoco frontier (Tarble de Scaramelli 2012) and female convicts in nineteenth-century British Australia (Casella 2012), or among peasants and colonized communities in ancient and modern Cyprus (Given 2004) and the ancient Mediterranean (Cañete Jiménez \& Vives-Ferrándiz Sánchez 2011; Zuchtriegel 2018), to cite some examples. The overfocus on rebellion and resistance necessary in the early 1990s to criticize the colonial idea of natives as passive receptors of 'superior cultures' in archaeology has in turn obliterated other forms of subaltern agency such as cooperation and compliance with the oppressors.

Gramsci, however, was more cautious when dealing with subaltern agency and crafted the concept of 'hegemony' the better to understand both subaltern passivity and subaltern resistance when confronted with the elite. 'Hegemony' refers to the political leadership of a particular group based on the consent of the led group; a consent that is obtained by the diffusion and naturalization of the worldview of the ruling class (Gramsci 1971, 56-7). Subaltern groups are thus subject and party to the hegemony of the ruling elite, even when trying to rebel. This is because 'domination operates by seducing, pressuring, or forcing ... members of subordinated groups and all individuals to replace individual and cultural ways of knowing with the dominant group's specialized thought-hegemonic ideologies that, in turn, justify practices of other domains of power' (Collins 2009, 287). Domination involves structural, disciplinary, hegemonic and interpersonal domains of power where 'oppressions of race, class, gender, sexuality, and nation mutually construct one another' (Collins 2009, 203).

Only few archaeologists have engaged with the notion of hegemony in their discussions of subalternity (cf. Bernbeck \& McGuire 2011; Emerson 1997; Routledge 2014; van Dommelen 2014), and even fewer with the concept of the 'matrix of domination' developed by Patricia Hill Collins (Battle-Baptiste 2016; Franklin 2001). Yet, if we are to understand subalternity and subordination in all its complexity, we need to address how different axis of oppression are at work and reproduced by subalterns.

\section{Intersective oppressions}

Scholars today deploy the concept of subalternity to refer to the condition of a person or a group of people hierarchically positioned as subordinate within imperial and/or colonial structures, dictatorial systems, international capitalism, nation states, relations of race, patriarchy, heteronormativity, religion, caste, class, age, or occupation (Gidwani 2009; Green 2002; 2011; Mani 1998). These categories of subordination are not exclusive, but deeply interrelated. In fact, it is only by understanding intersectionality at work, and more specifically the matrix of domination, that one can grasp the subaltern experience and its reproduction.

The concept of intersectionality, coined by Kimberlé Crenshaw in 1989, inherits a long history of struggle and Black feminist thought (Collins 2009; Hancock 2016). It stresses the structural and dynamic consequences of the interaction between several axes of oppression, namely race, ethnicity, sex, socioeconomic status, and so on, as inflicted onto marginalized people (Crenshaw 1989). Oppression cannot be reduced to one type; quite the contrary. Intersectionality looks at the overlap of oppressions that work together in producing unique inequality and injustice within a person.

An individual is always situated within different domains of power, from the macrolevel of social organization to the microlevel of interpersonal relationships. Therefore, for Collins $(2009,227-8)$, 'the overall social organization within which intersecting oppressions originate, develop, and are contained' is what defines a 'matrix of domination'. Although all matrices of domination encompass a combination of intersective oppressions, they are all different as to how the system of domination is organized, and 
thus they are historically situated and depend on the local context.

It is therefore the intersection of different axes of oppression in specific historical settings that constitutes the subaltern and, precisely because of that, subalternity is relational and dynamic within and in relation to dominant political forms (Crehan 2016, 60-62; Davis 2011; Nilsen \& Roy 2015). Yet, although most subalterns can identify their own victimization within the structural system of oppression-race, gender, class, religion, etc.- - they usually fail to see how their own actions in turn victimize/subordinate someone else. In fact, as Collins $(2009,287)$ points out, 'a matrix of domination contains few pure victims or oppressors'; for each individual, depending on their position within society, experiences different degrees of disadvantage and privilege from the multiple oppressive systems that frame everyone's lives. These experiences are contradictory within a person, and they are so routinized and recurrent in the everyday practices that they often go unnoticed-warns Collins $(2009,287)$. It is thus to the day-to-day experience that I turn now.

\section{The everyday life of subalterns and their senso comune}

Senso comune is a particularly useful tool to approach the everyday life of subaltern groups. Contrary to the English 'common sense' (meaning 'good sense and sound judgement in practical matters', according to the Oxford English Dictionary), senso comune refers to the beliefs and opinions of the masses that create a practical consciousness to confront their everyday life successfully. Since archaeologists deal mostly with the everyday life debris of people when excavating a site, exploring this concept and its application to archaeology could help us flesh the material remains to get a better understanding of subaltern people.

\section{Gramsci defined senso comune as}

not a single unique conception, identical in time and space ... it takes countless different forms. Its most fundamental characteristic is that it is a conception which, even in the brain of one individual, is fragmentary, incoherent and inconsequential, in conformity with the social and cultural position of those masses whose philosophy it is. (Gramsci 1971, 419)

Common sense is thus, for Gramsci, complex, unsystematic and messy. Based on foundational premises found in every human group, common sense provides a worldview that structures the basic sceneries within which individuals are socialized, including orientations that are historically and unconsciously adopted from dominant groups (Gramsci 1971, 326-7). These worldviews in which common sense is built upon are essential for every human being to understand reality, to interpret it and to act effectively within it, but they are also contradictory and uncritical (Baratta 2010; Crehan 2016, 46-7; Liguori 2005). Importantly, worldviews are modes of and for reality and thus they are different from one group to another, and that includes different segments within the same society-indeed, 'every social class has its own "common sense"' (Gramsci 1985, 420). This leads us again to the matrix of domination and the different systems of oppression and privilege that occur in a contradictory manner, i.e. everyday actions that reproduce or contradict ideology, being aware of your own victimization but not of your subalternization of others, etc.

The juxtaposition of the matrix of power developed by Collins and Gramsci's senso comune provides us with a broader and more complex framework to analyse subalternity and how it is reproduced within a given hegemony. Since subalterns tend to be ignored by official documents (but see Davis 2011), and it is in the day-to-day practices of interpersonal relations that subalternity is assumed and reinforced (Collins 2009, 287), the analysis of everyday material culture emerges as a very powerful tool to approach the subaltern experience (González-Ruibal 2014; Hansson et al. 2019; Liebmann 2012; van Dommelen 2006; 2014). Let me start by exemplifying this theoretical and methodological framework through the analysis of two case studies from Chile and Ethiopia.

\section{The Reche and the Spanish Empire: Chile, sixteenth-nineteenth centuries}

The Reche (today Mapuche) - inhabitants of centralsouthern Chile (Ngulu Mapu) and Argentina (Puel $\mathrm{Mapu}$ - - have been praised historically by anthropologists and archaeologists alike for vanquishing the Spaniards and their imperial power in the seventeenth century (Boccara 2008; Dillehay 2007; Sauer 2015). This is because, after many years of uprisings and war, the Reche defeated the Spaniards in 1598 and laid waste to all the colonial cities south of the Bíobío River (c. $500 \mathrm{~km}$ south from Santiago), forcing thousands of Spaniards and their allies to flee to Santiago. The Crown recognized the Reche ownership of their territory and established the imperial frontier along the Bíobío River in 1641. Despite being a great triumph-especially if compared with the fate of other colonized groups-overemphasizing 
this indigenous deed obscures ongoing colonial violence in the seventeenth and eighteenth centuries and downplays the suffering of subalterns in the region. Further, assuming the fierce resistance of all Reche against the Spaniards draws a homogeneous picture of indigenous people-and of the colonists -during the colonial period, disregarding other forms of agency such as collaboration and compliance with the colonial regime, or the subalternization of other segments of society by the Reche themselves.

\section{The Reche}

The Reche were a patriarchal and patrilocal society that practised exogamic polygyny-sororate marriage, specifically. Women were exchanged among different lineages through a bridewealth system in which the bride's family received animals, handwoven blankets and clothing from the groom's family in return for the loss of their daughter (Bengoa 2003, 83). This type of exchange created extensive kinship relationships among different and far-away communities, as well as intensive exchange networks across the Wallmapu-the Reche-Mapuche territory (Bengoa 2003, 79-86).

The household or lov was the basic social unit among the Reche, headed by the lonko [the father, referred to as 'cacique' by the Spaniards]. Several lovs formed a rewe, and several rewes an ayllareguesupra-organizations that took shape depending on ritual festivities and war, organized heterarchically and led always by men (Bengoa 2003, 159-70). This type of social structure was unconsciously adopted from the hegemonic leaders by all the Reche, as part of their common sense. Common sense, as we have seen, is contradictory and differs between societal segments. Many men within these communities did not occupy positions of power, and thus were subalternized by their leaders, but were nevertheless in charge of their lovs. Quite contrarily, women could not occupy positions of power or become the head of a lov, but accepted and reproduced their subordination within the social and political structure of the Reche communities.

The ruka [house] was the centre for everyday life activities among the Reche communities of centralsouthern Chile, and continues to play a pivotal role today (Fig. 1). The open-area excavation of the $\mathrm{Km}$ 0 -Enlace Temuco site in central Chile permitted the study of a ruka dating to the sixteenth century for the first time, yielding important information on everyday activities (Ocampo et al. 2005). Archaeologists uncovered two hearths (largest black circles in I5 and $\mathrm{K} 5$ in Figure 1a) and several circular areas with charcoal (I5, I7 in Figure 1a) interpreted as previous hearths no longer in use. The chroniclers concurred that there were as many hearths as wives living under the same $l o v$, and that each of the hearths had several pots, spits and pans (Zapater 1978, 53). If we accept this information, the two hearths would indicate the existence of at least two wives living in the ruka and married to the lonko.

The ruka did not present any internal division, but it seems that different activities were carried out in distinctive areas within the house. In the western side of the ruka, archaeologists unearthed numerous fragments of pottery, among them pots, tableware, and a tobacco pipe surrounding the hearths, which indicates the presence of cooking activities but also the social and ritual practice of smoking by the lonko. On the eastern side, associated with the post-holes, there were many and varied lithic artefacts, including several grinding stones and hand stones, an axe, as well as scrapers, flakes and blades. Grinding activities were quite prominent, as well as the preparation of leather and probably basketry, tool making and wood cutting and carving.

The existence of different types of stone raw materials (basalt, quartz, pumice, obsidian) coming from volcanos in the Andes $100 \mathrm{~km}$ away attest to the medium- to long-distance networks in which the mainland Reche were involved, most likely as a result of marriages. These types of networks as providers of raw materials are also demonstrated by the analysis of obsidian from the sixteenth-century site of Santa Sylvia, where black obsidian came from a nearby volcano and red obsidian came from Neuquén in Argentina, $150 \mathrm{~km}$ away (Sauer 2015, 111-12). Either as bridewealth or as a consequence of the establishment of a reciprocity system because of the marriage, obsidian was clearly exchanged between coastal, mainland and Andean groups.

Similar material culture to that found at $\mathrm{Km}$ 0 -Enlace Temuco was unveiled from the domestic sites of La Mocha Island in the Pacific (Quiroz \& Fuentes-Mucherl 2012; Quiroz \& Sánchez 1997); and surveys and test pits in the area of Valdivia yielded comparable evidence before and during the colonial period (Marín-Aguilera et al. 2019, 89-91). This means that the ruka was the materialization of both the social structure and the interpersonal relations of all Reche communities between the fourteenth-fifteenth century and the nineteenth century (Fig. 1b).

Spanish chronicles and ethnography provide us with details regarding the sexual division of labour among the Reche, accepted and unconsciously reproduced by all community members. Ploughing the 

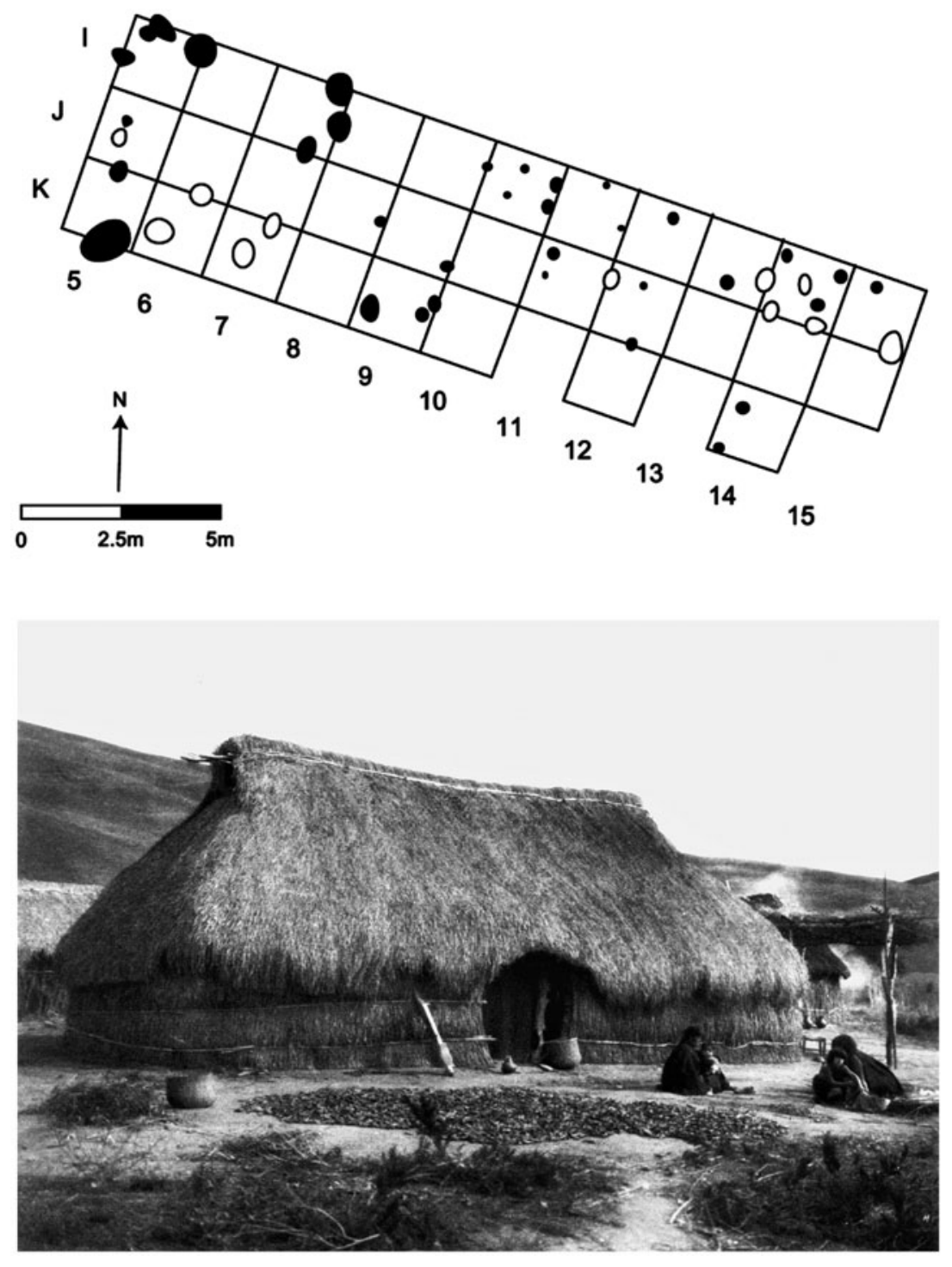

Figure 1. (Above) Archaeological remains of a Reche ruka (after Ocampo et al. 2005 \& Dillehay 2014, 108); (below) postcard showing a ruka Mapuche in the early twentieth century.

land was a communal activity carried out by several lonkos from different lovs, whilst women were in charge of sowing; after which the lonko who owned the fields organized a big festivity with food and alcoholic drinks - prepared by his wives-for all participants (Zapater 1978, 52-3). Other important economic activities were boat building and fishing and sea-food gathering-done by men-and trade, basketry, textile and pottery making carried out by women (Bengoa 2003, 79-83; Zapater 1978, 54, 9093) (Fig. 2).

The more wives a lonko had, the wealthier he was, for he profited from a greater exchange network and higher agricultural and textile productivity. Not all lonkos could pay the bride price several times and thus have more than one wife; and not all wives were equal within the lov. The first one seemed to have been the most important wife-accepted as such by the others-in charge of organizing the work of all other wives in the lov (Zapater 1978, 63). We see here how socio-economic differences and women's status played a role in the worldviews of each lonko and each wife.

The Spanish conquest and colonization

The Spanish Crown formally abolished indigenous slavery in 1542 (New Laws), a year after the foundation of the first colonial city in Chile. However, 'rebel Indians' could be officially enslaved, no matter whether children or adults. As a result, thousands of Reche who waged war and rebelled against the Spaniards were owned and/or sold as slaves to other Spaniards living in other regions of the Empire; females were raped and constrained to 


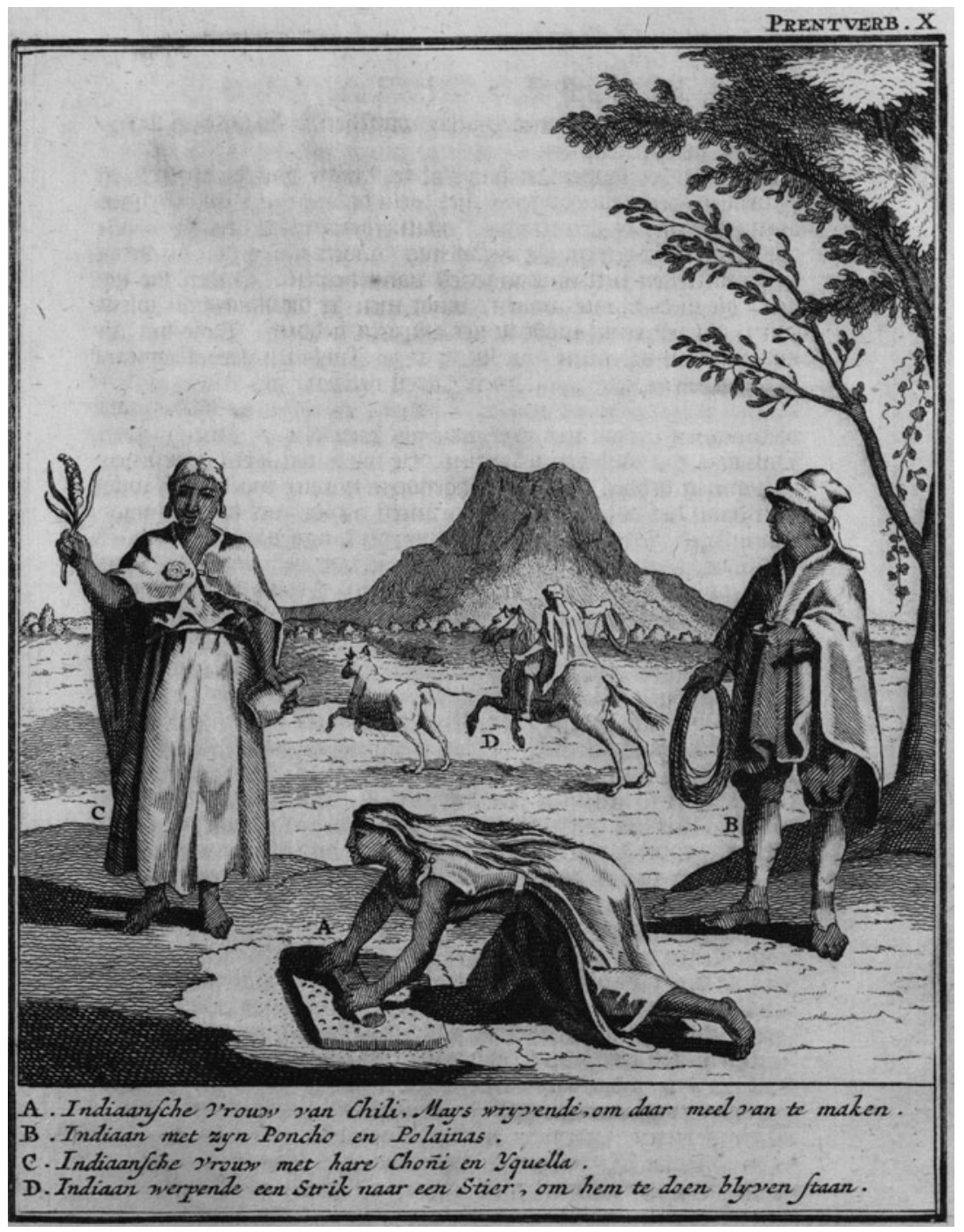

Figure 2. Reche women engaged in everyday activities. (Engraving for A.F. Frézier, Relation du voyage de la mer du Sud aux côtes du Chili, du Pérou, et du Brésil, fait pendant les années 1712, 1713, \& 1714. (Courtesy of the John Carter Brown Library, Brown University.)

The Reche common sense, however, or their het-

work in colonial households, and many men swelled the encomiendas - forced tribute and labour systemin different regions of Chile (Contreras Cruces 2016; Valenzuela 2009).

The Reche were confronted with a hierarchical political system and with an alien social structure in which the white Spaniards and their criollo descendants were on top, whereas the indigenous, Africans and their descendants were below. There was social mobility, however, and indigenous people and freed Africans could climb the social ladder (Rappaport 2014; Sater 1974; Walker 2017). In fact, in the period between 1564 and 1801, 60.9 per cent of all indigenous last wills in colonial Chile belonged to Reche individuals who integrated well into the colonial society (Retamal Ávila 2000, 26), and freed Africans got encomiendas in Chile with indigenous forced labour (Sater 1974). erogeneous bundle of taken-for-granted worldviews, suffered a profound transformation in which a different hegemonic worldview and a new set of everyday practices were imposed upon them, replacing the previous unconscious adoption of their own political, social and cultural structure. Yet, the Reche elite also profited from their new situation, possessing themselves indigenous people as domestic servants and slaves (Retamal Ávila 2000, 76-7).

Beyond the imperial frontier at the Bíobío River, wars, slavery and the encomienda system decimated the Reche population and their resources. Before the arrival of the Spaniards, the Reche carried out malocas [raids to get animals and other goods] to implement justice among different lovs (Parentini 1999). However, in the late seventeenth century and especially in the eighteenth, the scarcity of resources 
led to a transformation of the malocas from a justice system to a fight over the control of resources among different lows, which included incursions into Spanish territories to steal livestock, horses and women (León 1991).

This transformation of the malocas heavily impacted the Reche bridewealth and reciprocity system, as well as their interpersonal domain and social structure. By taking Spanish women as captives, the lonkos avoided the bride price but added wives and thus labour force to the lov. In fact, the Reche forced female captives to dress as Reche women, work in the fields, prepare and cook food and drinks, spin and weave textiles and have intimate relations and procreate with the lonkos who owned them (Lázaro Ávila 1994). They basically forced them to become Reche. New language, new behavioural rules, new beliefs and rituals and new material practices joined the existing agglomerate of the Spanish women's common sense, that mutated considerably.

Excavated colonial contexts in today's centralsouthern Chile always display a mixture of Spanish and Reche material culture, the latter often being more numerous (Dillehay 2014, 97; Marín-Aguilera et al. 2019; Sauer 2015, 96-111). This indicates that even when the Reche were domestic servants, slaves, or forced labourers in encomiendas, they kept their everyday materiality and could cling to their everyday practices, such as their own cuisine cooked and served in their own ceramics or smoking tobacco from their own pipes, in the case of the men.

Yet, in the rukas excavated and dated to the colonial period, the amount of Spanish material culture is either non-existent or extremely scarce (cf. Adán et al. 2016). This means that Spanish captives, and particularly females, went through an almost complete transformation of their common sense. Everyday activities such as food preparation and consumption, dressing habits and the Reche socialization of their new-borns were completely alien to them. They suffered the sexual abuse by the lonkos that the Spanish men inflicted on indigenous and African females taken as slaves and domestic servants. Female bodies became the site of colonial violence in Chile, but Spanish females eventually became integrated into the Reche society as any other wife, whereas both indigenous and African slaves continued to be servants. The matrix of domination was, thus, quite different between women.

The Spanish conquest and colonization of Chile brought misery and suffering not only to Africans, indigenous people and their descendants, but also to many Spanish men and especially women. While Spanish elite men mostly kept their common sense intact (same hierarchical system, same religion, similar houses and everyday material culture, etc.), all Africans, most indigenous people and many Spaniards saw their worldviews and systems of oppression, previously unconsciously understood and performed, dramatically change, destabilizing their life courses. Hence, harping on the Reche resistance and defeat of the Spaniards neglects the heterogeneity of the Reche and silences the enduring of imperial violence by many Reche communities, among other ethnic groups in colonial Chile.

\section{The Gumuz, Ethiopia (sixteenth century-today)}

The Gumuz inhabit the present borderland between Sudan and Ethiopia, where they have lived since at least the fifteenth century $\mathrm{AD}$ according to historical sources, although it is likely that they inhabited the area already in antiquity (González-Ruibal 2014, 93-4). Through different strategies of resistance, these groups have, to different degrees, managed to avoid their full incorporation into the State (González-Ruibal 2014; James 2016; Jedrej 2006). Heavily racialized and discriminated againstdescribed as evil black and wild animals (GonzálezRuibal 2014, 91-2) — the Gumuz have been raided and enslaved for centuries by their neighbours (Ahmad 1989; 1999; Taddesse Tamrat 1988).

The Gumuz are always described as 'egalitarian societies' sustained by 'egalitarian ethics' because of the absence of hierarchies and socio-economic differences (Feyissa Dadi 2011, 266; González-Ruibal 2014; James 1979, 19). Yet egalitarian societies, at least in the case of the Gumuz, are not equal. Women occupy a subaltern position within their communities (Hernando 2017; 2020). Thus, behind a history of cruel violence and subalternization lies a history of gender asymmetries that is neglected by the discourses crafted by most anthropologists, archaeologists and sociologists that have worked with/about the Gumuz.

\section{The shared racial oppression}

Racial ideas in Ethiopia date back to at least $400 \mathrm{BC}$, when a Sabean inscription refers to 'black' and 'red' subjects of a king (Taddesse Tamrat 1982, 342). Highland Ethiopians have never seen themselves as black, but as red, and have always perceived lowland groups-among them the Gumuzas blacks, and thus subject to slavery (GonzálezRuibal 2014, 92-4). Slavery of lowlanders was made official by the Fethä Nägäst [Law of the Kings] dating to the thirteenth century, which permitted the enslavement of non-Christian war captives and of 
polytheists living on the fringes of Christian Ethiopia (Ware 2011, 73). Behind this profitable slave market was the acquisition of Indian textiles by Christian Abyssinia (Eaton 2005, 108-9). In order to obtain them, the Solomonic kingdom refrained from baptizing pagan communities (even if some begged to be Christian) so they could capture and sell them to Muslim traders in exchange for Indian commodities, according to the Jesuit Gonçalo Rodrigues in 1556 (Pankhurst 1997, 252-3). Indeed, between the fourteenth and seventeenth centuries, Muslims and Christians acquired most of the slaves from pagan communities (Eaton 2005, 108-10), and c. 10,00012,000 of them annually left Ethiopia (Pankhurst 1997, 253). From 1640 onwards, the Ethiopian state expanded its slave-raiding expeditions towards its western frontier with Sudan, the area inhabited by the Gumuz (Pankhurst 1990, 111-12). Defined as 'blacks' and derogatorily referred to as 'Shanqalla', the Gumuz suffered slave-raids until at least the mid twentieth century (González-Ruibal 2014, 94-5). The traveller James Bruce explained when and how those raids took place in the eighteenth century:

on the accession of every new king to the throne of Abyssinia, there is, among other amusements, a general hunt after the Shangalla. Inroads are made upon them, also, from time to time by the governors of the adjacent countries, who are obliged to render as tribute to the king of Abyssinia a certain number of slaves. When a settlement is surprised, the men are slaughtered, the women who are not slain kill themselves, or go mad; and the boys and girls are taken to be educated as slaves for the palace and the great houses of Abyssinia. (Bruce $1860,81-2)$

The Gumuz villages on the Sudanese-Ethiopian border clearly embody the fear of being raided. Entering a Gumuz settlement is a 'similar experience to that of accessing a labyrinth, with closed alleys, narrow passages, funnel-shaped entrances and exits, countless junctions and unexpected open spaces' (GonzálezRuibal et al. 2009, 88). Since one cannot see the whole village, it is difficult to get an idea of its layout, making it easier for the Gumuz to defend themselves, but also better to escape a slave raid. The act of escaping is better expressed by the construction of the Gumuz house, that always has a back door for the sole purpose of fleeing slave raids (Fig. 3) even today, when they do not suffer them. The architecture of trauma is deeply embedded in the bodily experience of the Gumuz, and thus, as the team of archaeologists working on the Gumuz territory point out, 'Gumuz identity is inseparable from their houses: they are built together' (González-Ruibal et al. 2009, 88). This type of architecture is the material debris of the worldview in which the Gumuz have been socialized for centuries and, according to which, they have charted their life courses.

Trauma is also inscribed in their bodies through scarification (mokota). One particular type of this body decoration that is almost always present is an encircled cross, the shangi. The first evidence of this type of scarification comes from $\mathrm{AD} 1600$, when the governors of the Funj Kingdom, who conquered the Ethiopian-Sudanese borderland, marked their slaves and herds with it (González-Ruibal 2014, 126). As a symbol of an experience they cannot escape-slavery-this type of scarification is both a remnant of an unconsciously adopted hegemonic worldview from the traumatic Funj period and the social landscape in which the Gumuz are socialized. Indeed, far from seeing it as a symbol of subalternity, they see it as part of their identity as Gumuz (Fig. 4). Men usually have it only on their cheeks, whereas women have them on their back, arms, breasts and stomach as a sign not only of group identity but of beauty (Hernando 2017, 455-6). Associated with fertility, the shangi also features prominently in the decoration of Gumuz material culture, such as in their granaries and in the sticks Gumuz females use for dancing (González-Ruibal 2014, 126).

The Gumuz have also reworked, in quite a contradictory way, their association with the Funj in their oral tradition. In fact, they see themselves as Funj:

Why do they [the Ethiopians] say Shankalla? The reason is this: because they want to sell these Shankalla people and make them slaves. But we are Funj... The Funj are the people who used to be called el hurra [freemen in Arabic]; now we are not slaves, but Funj and freemen. (Quoted in James 1988, 135)

This could be also the reason-or one of the reasons - the Gumuz continue to use the shangi as part of their everyday bodily and visual landscape. It would explain as well why this scarification is far more popular among the Gumuz than among other groups that were also enslaved but scarcely use it (González-Ruibal 2014, 126).

As part of their shared common sense, the Gumuz have also inherited a sense for resistance against the abuse they have historically suffered. Their everyday material culture for preparing food and consuming it is made of basketry or clay, and they rarely rely on ceramics, baskets, or plastic containers coming from their neighbouring groups or from the market, in contrast to the nearby Agäw (González-Ruibal 2014, 119-23). 


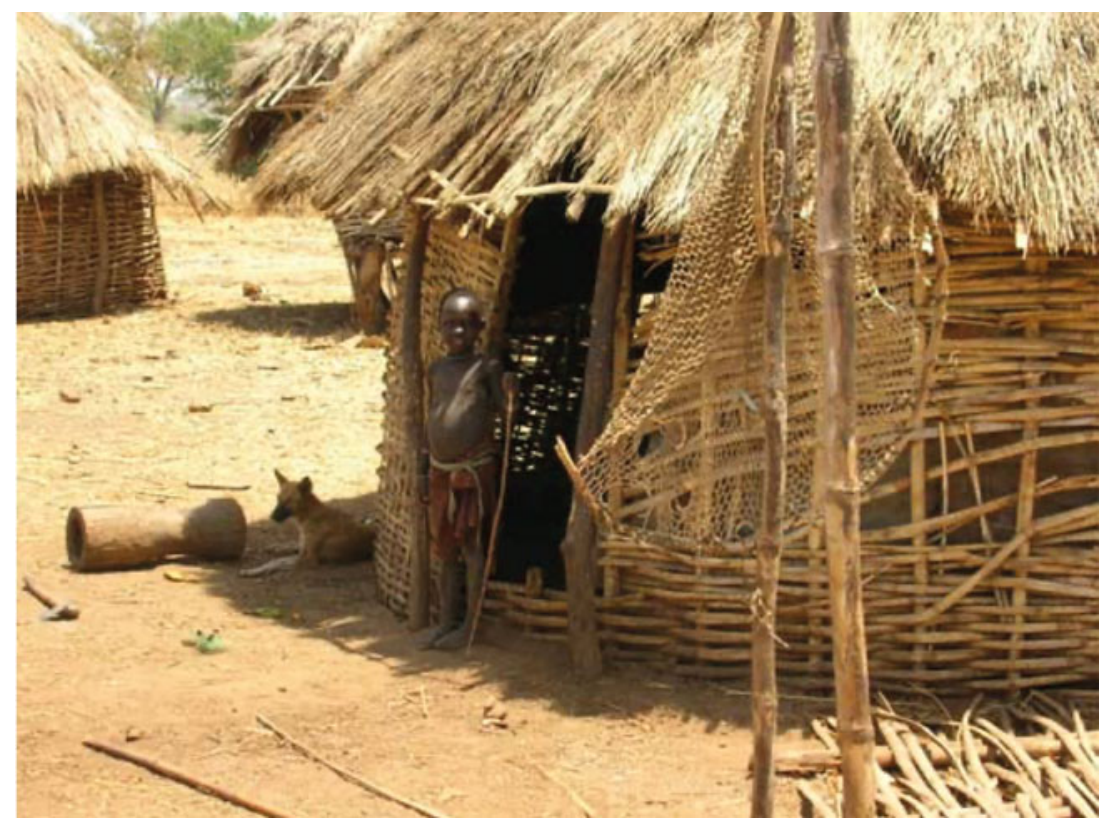

Figure 3. Typical back door of a Gumuz house. (Photograph: courtesy of Alfredo González-Ruibal.)

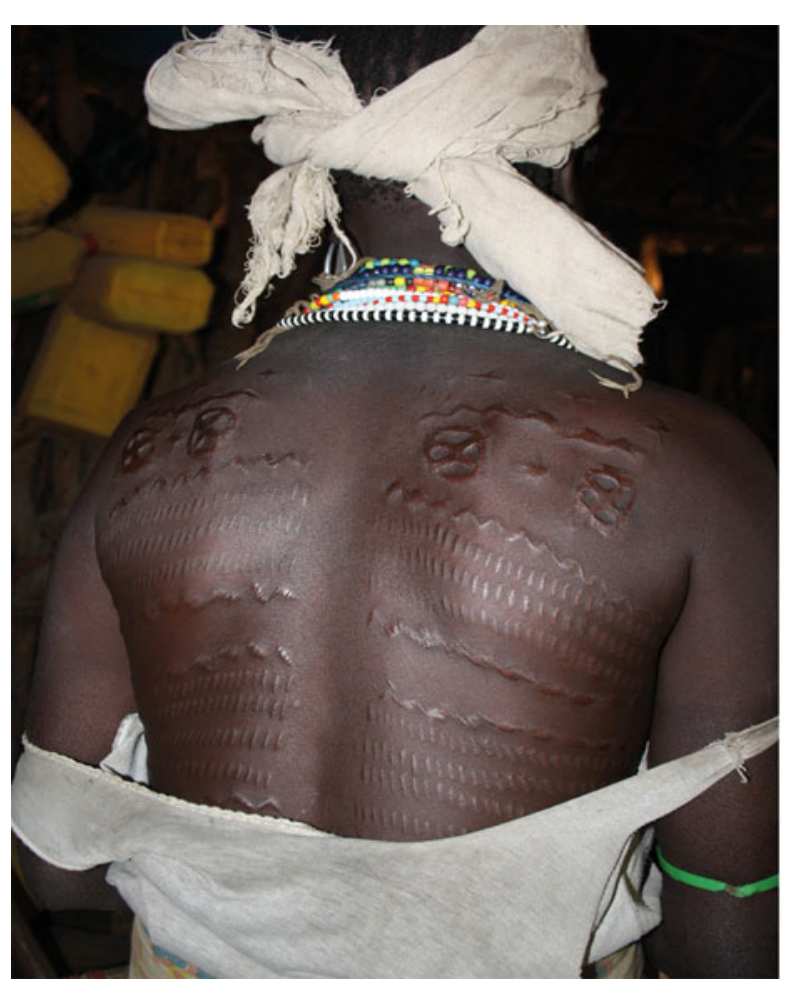

Figure 4. Gumuz woman with scarification on her back —note the encircled cross. (Hernando, 2017, fig. 7, with permission.)

Until the mid nineteenth century, the Gumuz exchanged sisters in marriage with the Agäw and frequently traded with them, but in the late nineteenth century the situation changed (James 1988, 134-5).
The Agäw completed their conversion to Christianity by the second half of the nineteenth century and thus did not suffer more slave-raiding; moreover, they acted as tribute collectors from the Gumuz for Christian Ethiopia (Ahmad 1995, 56-8). The Gumuz were thus left between the Christian empire of Ethiopia and the Madhist Sudan, whose expansion and conversion policies to Christianity and Islam, respectively, heavily pressured them. New slave-raids and pillage by both empires against the Gumuz in the early twentieth century forced hundreds of them to flee and abandon their villages (Ahmad 1995; 1999; James 1988). In fact, there is a hiatus in the archaeological record of this period in the region attesting to the escape and exile of many Gumuz communities (González-Ruibal \& Falquina 2017, 196-7). This recent traumatic experience probably explains the reluctance of the Gumuz to use alien material culture, particularly from the Agäw, who however do use Gumuz pots as part of their everyday ceramic repertoire.

The intersection of gender

United by racial oppression and slave-raiding, the Gumuz display another level of subalternity that is not external to them but internal to their worldview and practices: that of the Gumuz women (Hernando 2017; 2020). Even when being racialized and enslaved, it is young women and girls who historically suffered most slave raids (Ahmad 1999, 439). Gumuz women carry out most economic tasks such as household chores, weeding and ploughing on 
Figure 5. A Gumuz village with main house (right) and kogwa for menstruating teenagers (left). (Photograph: courtesy of Alfredo González-Ruibal.)

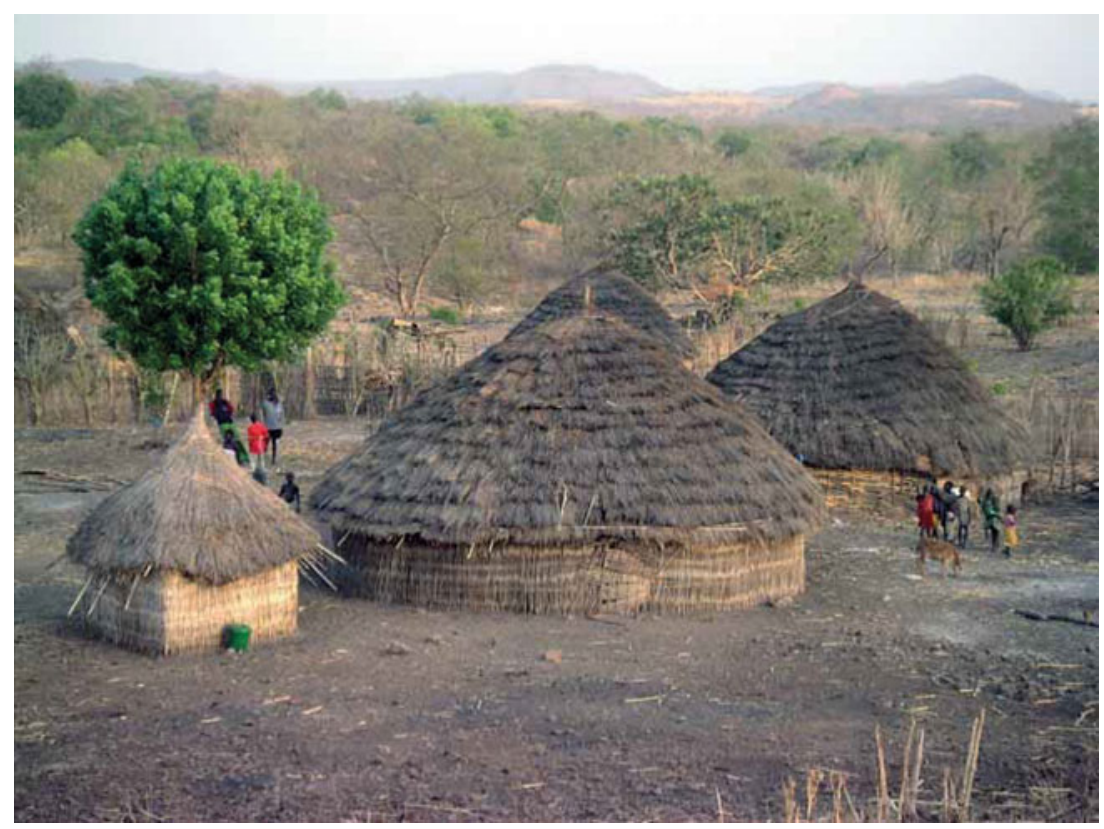

the farm, collecting firewood, carrying heavy loads to the market, fetching water and taking care of children (Birhan \& Zewdie 2018; Zeleke 2010). In many areas, Gumuz girls are not schooled (Zeleke 2010, $42)$, and women are beaten by their husbands (González-Ruibal 2014, 132-3).

Women are believed to be polluted at menarche and during the first two menstrual periods, as well as when giving birth, and they are therefore secluded from the community (González-Ruibal 2014, 132-3). This type of subalternization, accepted and reproduced by Gumuz women, is embodied by architecture. During their first two menstrual periods, women live in a separate hut called mets'a gaya (Fig. 5). Further, there are specific types of material culture that women need to use when menstruating so as not to mix with the rest of everyday material culture shared by the family and group. Among these items, they are required to wear a particular belt around their waist, to sit on specific stools only used during menstruation (tuga gaya) and to use specific pots (González-Ruibal 2014，145-6; Kidanemariam Demellew 1987, 23, 26).

Mothers give birth in isolation in the woods without making much noise during labour because it would make the Missa [spirits] angry; after which, they need to remove the placenta, cutting the umbilical cord, and washing the newborn themselves (Kidanemariam Demellew 1987, 22; Zeleke 2010, 36). Many women have died giving birth because the baby was in the wrong position during labour, and many others could not return home until they were completely clean from blood many days later -and many Gumuz women are now rebelling against these practices and beliefs (Negash 2017).

Both menstruation and pregnancy practices have been adopted and reproduced by Gumuz women for centuries as part of their common sense, and Gumuz beliefs shared by the community have acted to consolidate them. Whilst materiality embodies the pollution taboos around menstruation among the Gumuz-huts, material culture-the material silence of giving birth is overwhelming.

Gumuz women are thus embedded in a matrix of power in which they suffer the intersecting oppression of race and gender, whereas men experience only the racial oppression. Lack of social hierarchies and communal and shared practices, among other aspects, point to egalitarian societies (González-Ruibal 2014, 112-24), but the Gumuz are far from equal in terms of gender (Hernando 2017; 2020). Our reiterative narratives of egalitarianism have the power to produce and stabilize the very effects of subalternity, silencing, in the case of the Gumuz, the subalternization of women.

\section{Subaltern debris}

The interest in the subaltern(s) in archaeology runs parallel to a general interest in questions of power, agency and resistance in the humanities and social sciences. Eagerly adopted by some and rejected by others, the concept of the subaltern has the potential 
to overcome identity deadlocks and provide a useful framework to compare the manifestation of subalternity and its reproduction by subalterns themselves. The combination of Gramsci's senso comune and Collins' 'matrix of domination' further strengthens a theoretical and methodological skeleton to identify the different elements which comprise subalternity and the social realities to which they are linked. It stresses the situational and relational context in which subalterns chart their life courses. Most importantly, the concept of the subaltern as the axis of intersecting oppressions escapes homogenizing visions of human groups and their material culture. The debris of everyday practices emerges thus as a powerful tool to map the contradictory elements of common sense and how materiality embodies the different intersecting oppressions at play within subalterns.

Due to limited space, the two case studies briefly examined here do not aim to be conclusive regarding the application of the proposed theoretical and methodological framework, but to open new ways of thinking about subaltern experiences through the use of material culture. In Chile, the ruka functions as the embodiment of the Reche common sense in the way it structures different social and economic activities as well as people living under its roof. It also provides a shared point of departure for all Reche in central-southern Chile, being the basic mechanism through which individuals internalize hegemonic worldviews and effective tools to understand reality and to act upon it. For Spanish captives, however, the ruka represents the alienation and violence suffered and lived as part of their captivity, and a completely new set of heterogeneous debris of worldviews and daily practices waiting to be understood to make sense of their new experience. The material culture of Spanish houses and haciendas, however, allows indigenous communities to cling to their traditional social practices. Yet they are immersed in a completely new matrix of domination which I could only sketch out here. Differences between forced labourers and Reche elite are important, for the former suffered racial, socio-economic, religious and gender oppression, whereas the latter did not suffer the tyranny of poverty and lack of freedom.

The case of the Gumuz is quite different, as they cling to communal and egalitarian practices to avoid the development of social and economic hierarchies. The Gumuz, however, have shared a common axis of oppression for centuries, i.e. race, for which they have been subalternized by every group and expanding state or empire since the fifteenth century and, most crucially, enslaved and killed. Still, Gumuz women experience a double subalternization by the intersection of their racialized oppression shared with men and the violence and subjugation practices felt as women.

What the combination of Gramsci's senso comune and Collins' 'matrix of domination' offers archaeologists is a way of thinking about everyday practices that encompasses both their contradictions and flexibility, as well as their subjective diversity. By fleshing material culture and keeping the focus on how materiality embodies different systems of oppression, subalternity can be explored.

\section{Acknowledgements}

This research was generously funded by the McDonald Grants and Awards 2017-2019 (McDonald Institute for Archaeological Research, University of Cambridge) and the Spanish Ministry of Science, Innovation and Universities (HAR2016-77564-C2-2-P). I thank Almudena Hernando for her comments and image of the Gumuz woman, and Alfredo González-Ruibal for the two other images of the Gumuz. I am also grateful for the feedback of the editor and three reviewers on an earlier version of this article, and for the long discussions about subalternity and Gramsci with Peter van Dommelen.

\section{Beatriz Marín-Aguilera McDonald Institute for Archaeological Research University of Cambridge \\ Downing Street Cambridge CB2 3ER UK \\ Email:bm499@cam.ac.uk}

\section{References}

Adán, L., S. Urbina, C. Prieto, V. Zorrilla \& L. Puebla, 2016. Variedad y distribución del material cerámico de tradición hispana e indígena en la ciudad de Valdivia y su jurisdicción entre los siglos XVI y XVIII [Variety and distribution of ceramics of Hispanic and indigenous tradition in the city of Valdivia and its jurisdiction between the 16th and 18th centuries], in Primeros Asentamientos Españoles y Portugueses En La América Central y Meridional: Siglos XVI y XVII [First Spanish and Portuguese settlements in Central and South America: 16th and 17th centuries], eds L.M. Calvo \& G. Cocco. Santa Fe: Universidad Nacional del Litoral, 251-73.

Ahmad, A.H., 1995. The Gumuz of the Lowlands of Western Gojjam: The frontier in history, 1900-1935. Africa 50(1), 53-67.

Ahmad, A.H.A., 1989. Ethiopian slave exports at Matamma, Massawa and Tajura, c. 1830-1885, in 
The Economics of the Indian Ocean Slave Trade, ed. W.G. Clarence-Smith. London: Frank Cass, 93-102.

Ahmad, A.H.A., 1999. Trading in slaves in Bela-Shangul and Gumuz, Ethiopia: border enclaves in history, 1897-1938. Journal of African History 40(3), 433-46.

Antonaccio, C., 2013. Networking the middle ground? The Greek diaspora, tenth to fifth century BC. Archaeological Review from Cambridge 28(1), 241-55.

Arnold, D., 1984. Gramsci and peasant subalternity in India. Journal of Peasant Studies 11(4), 155-77.

Banerjee, P., 2015. The subaltern: political subject or protagonist of history? South Asia: Journal of South Asian Studies 38(1), 39-49.

Baratta, G., 2010. Scuola Filosofia Cittadinanza nel pensiero di Gramsci: Esercizi di lettura [School of philosophy and citizenship in Gramsci's thought: reading exercises]. Pro-Posições 21(1), 1-16.

Battle-Baptiste, W., 2016. Black Feminist Archaeology. Abingdon: Routledge.

Bengoa, J., 2003. Historia de Los Antiguos Mapuches Del Sur. Desde Antes de La Llegada de Los Españoles Hasta Las Paces de Quilin [History of the ancient Mapuches from the south. From before the arrival of the Spaniards till the Quilín Peace Agreement]. Santiago de Chile: Editorial Catalonia.

Bernbeck, R. \& R.H. McGuire, 2011. A conceptual history of ideology and its place in archaeology, in Ideologies in Archaeology, eds R. Bernbeck \& R.H. McGuire. Tucson (AZ): University of Arizona Press, 15-59.

Birhan, W. \& T. Zewdie, 2018. Marriage practices and gender role socialization among the Gumuz of Ethiopia, African Journal of History and Culture 10(4), 51-6.

Boccara, G., 2008. Los Vencedores. Historia del Pueblo Mapuche en la Época Colonial The vanquishers. History of the Mapuche people in the colonial era]. San Pedro de Atacama/Santiago: Línea Editorial IIAM-UCN/Universidad de Chile.

Brass, T., 2017. Who these days is not a subaltern? The populist drift of global labor history. Science and Society 81(1), 10-34.

Bruce, J., 1860. Bruce's Travels and Adventures in Abyssinia. Edinburgh: Adam \& Charles Black, North Bridge.

Burnard, T. \& G. Heuman, 2011. Introduction, in The Routledge History of Slavery, eds G. Heuman \& T. Burnard. Abingdon/New York: Routledge, 1-15.

Cañete Jiménez, C. \& J. Vives-Ferrándiz Sánchez, 2011. 'Almost the same': dynamic domination and hybrid contexts in Iron Age Lixus, Larache, Morocco. World Archaeology 43(1), 124-43.

Casella, E.C., 2012. Little bastard felons: childhood, affect, and labour in the penal colonies of nineteenthcentury Australia, in The Archaeology of Colonialism: Intimate encounters and sexual effects, eds B.L. Voss \& E.C. Casella. Cambridge: Cambridge University Press, 31-48.

Chakrabarty, D., 2000. Provincializing Europe: Postcolonial thought and historical difference. Princeton (NJ): Princeton University Press.
Chatterjee, P., 2010. Reflections on 'Can the Subaltern Speak?' Subaltern Studies after Spivak, in Can the Subaltern Speak?: Reflections on the history of an idea, ed. R.C. Morris. New York (NY): Columbia University Press, 81-6.

Chaturvedi, V., 2000. Introduction, in Mapping Subaltern Studies and the Postcolonial, ed. V. Chaturvedi. London: Verso, vii-xix.

Collins, P.H., 2009. Black Feminist Thought. London/ New York: Routledge.

Contreras Cruces, H., 2016. Migraciones locales y asentamiento indígena en las estancias españolas de Chile central, 1580-1650 [Local migration and indigenous settlement in the central Chilean Spanish estancias, 1580-1650]. Historia 49(1), 87-110.

Crehan, K., 2016. Gramsci's Common Sense: Inequality and its narratives. Durham (NC): Duke University Press.

Crenshaw, K., 1989. Demarginalizing the intersection of race and sex: a black feminist critique of antidiscrimination doctrine, Feminist theory, and antiracist politics. University of Chicago Legal Forum 1989(1), article 8.

Croucher, S.K., 2015. Capitalism and Cloves: An archaeology of plantation life on nineteenth century Zanzibar. New York (NY): Springer.

Cuozzo, M. \& C. Pellegrino, 2016. Culture meticce, identità etnica, dinamiche di conservatorismo e resistenza: questioni teoriche e casi di studio dalla Campania [Mestizo culture, ethnic identity, dynamics of conservatism and resistance: theoretical issues and case studies from Campania], in Contextualising Early Colonisation, eds L. Donnellan, V. Nizzo, G.-J.L.M. Burgers \& R. Osborne. Brussels: Belgisch Historisch Insituut te Rome, 117-36.

Davis, N.Z., 2011. Decentering history: local stories and cultural crossings in a global world. History and Theory 50(2), 188-202.

De Kock, L. \& G.C. Spivak, 1992. Interview with Gayatri Chakravorty Spivak: New Nation Writers Conference in South Africa. Ariel: A Review of International English Literature 23(3), 29-47.

Delgado Hervás, A.M., 2010. De las cocinas coloniales y otras historias silenciadas: domesticidad, subalternidad e hibridación en las colonias fenicias occidentales [On colonial cuisines and other silenced stories: domesticity, subalternity and hybridity in the western Phoenician kitchens], in De La Cuina a La Taula: IV Reunió d'economia En El Primer Mil-lenni AC [From the kitchen to the table: IV Meeting of First Millennium BC Economy], eds C. Mata Parreño, G. Pérez Jordá \& J. Vives-Ferrándiz Sánchez. València: Universitat de València, 27-42.

Dietler, M., 2010. Archaeologies of Colonialism: Consumption, entanglement, and violence in ancient Mediterranean France. Berkeley/Los Angeles: University of California Press.

Dillehay, T.D., 2007. Monuments, Resistance and Empires in the Andes: Araucanian ritual narratives and polity. Cambridge: Cambridge University Press. 
Dillehay, T.D., 2014. The Teleoscopic Polity: Andean patriarchy and materiality. Berlin: Springer.

Eaton, R.M., 2005. A Social History of the Deccan, 1300-1761: Eight Indian lives. Cambridge: Cambridge University Press.

Emerson, T.E., 1997. Cahokia and the Archaeology of Power. Tuscaloosa (AL): University of Alabama Press.

Fanon, F., 1952. Peau Noire, Masques Blancs [Black skin, white masks]. Paris: Fanon.

Ferris, N., R. Harrison \& M.V. Wilcox (eds), 2014. Rethinking Colonial Pasts Through Archaeology. Oxford: Oxford University Press.

Feyissa Dadi, G., 2011. Etnoarqueología, Identidad y Cultura Material de Un Pueblo Fronterizo Africano: Los Gumuz de Etiopía Occidental [Ethnoarchaeology, identity and material culture of an African frontier community: the Gumuz of western Ethiopia]. Madrid: Universidad Complutense de Madrid.

Franklin, M., 2001. A Black feminist-inspired archaeology? Journal of Social Archaeology 1(1), 108-25.

Gidwani, V., 2009. Subalternity, in International Encyclopedia of Human Geography, eds N. Thrift \& R. Kitchen. Amsterdam: Elsevier Science, 65-71.

Given, M., 2004. The Archaeology of the Colonized. London: Routledge.

Gnecco, C. \& P. Ayala (eds), 2011. Indigenous Peoples and Archaeology in Latin America. Walnut Creek (CA): Left Coast Press.

Gomes Coelho, R., 2009. Comportamentos de resistência à integração colonial na Amazónia portuguesa (século XVIII) [Resistance to colonial integration in the Portuguese Amazon (18th century)]. Anais de História de Além-Mar 10, 129-84.

González-Ruibal, A., 2014. An Archaeology of Resistance: Materiality and time in an African borderland. Lanham (MD): Rowman \& Littlefield.

González-Ruibal, A., 2019a. Ethical issues in indigenous archaeology: problems with difference and collaboration. Canadian Journal of Bioethics 2(3), 34-43.

González-Ruibal, A., 2019b. An Archaeology of the Contemporary Era. Abingdon/New York: Routledge.

González-Ruibal, A., X. Ayán \& Á. Falquina, 2009. Deep-mapping the Gumuz house, in Archaeotecture: Second Floor, eds X. Ayán, P. Mañana \& R. Blanco. (BAR International series S1971). Oxford: Archaeopress, 79-96.

González-Ruibal, A. \& Á. Falquina, 2017. In Sudan's eastern borderland: frontier societies of the Qwara region (ca. AD 600-1850). Journal of African Archaeology 15, 173-201.

Gopal, P., 2004. Reading subaltern history, in The Cambridge Companion to Postcolonial Literary Studies, ed. N. Lazarus. Cambridge: Cambridge University Press, 139-61.

Gramsci, A., 1971. Selections from the Prison Notebooks of Antonio Gramsci. London: Lawrence \& Wishart.

Gramsci, A., 1975. Quaderni del Carcere [Prison notebooks]. Turin: Einaudi.
Gramsci, A., 1985. Antonio Gramsci: Selections from cultural writings. London: Lawrence \& Wishart.

Greco, G. \& F. Mermati, 2011. Kyme in Opicia: a new perspective. Archaeological Reports 57, 109-18.

Green, M.E., 2002. Gramsci cannot speak: presentations and interpretations of Gramsci's concept of the subaltern. Rethinking Marxism 14(3), 1-24.

Green, M.E., 2011. Rethinking the subaltern and the question of censorship in Gramsci's Prison Notebooks. Postcolonial Studies 14(4), 387-404.

Green, M.E., 2013. Race, class, and religion: Gramsci's conception of subalternity, in The Political Philosophies of Antonio Gramsci and B.R. Ambedkar: Itineraries of Dalits and subalterns, ed. C. Zene. New York (NY): Routledge, 116-28.

Guha, R., 1988a. Preface, in Selected Subaltern Studies, eds R. Guha \& G.C. Spivak. New York (NY): Oxford University Press, 35-36.

Guha, R., 1988b. On some aspects of the historiography of colonial India, in Selected Subaltern Studies, eds R. Guha \& G.C. Spivak. New York (NY): Oxford University Press, 37-44.

Guha, R., 1988c. The prose of counter-insurgency, in Selected Subaltern Studies, eds R. Guha \& G. C. Spivak. New York (NY): Oxford University Press, 45-86.

Hall, M., 2000. Archaeology and the Modern World: Colonial transcripts in South Africa and Chesapeake. London: Routledge.

Hancock, A.-M., 2016. Intersectionality: An intellectual history. Oxford: Oxford University Press.

Hansson, M., P. Nilsson \& E. Svensson, 2019. Invisible and ignored: the archaeology of nineteenth century subalterns in Sweden. International Journal of Historical Archaeology 24, 1-21.

Hernando, A., 2017. Cuerpo, cultura material y género entre los Gumuz y Dats'in (Etiopía) [Body, material culture and gender among the Gumuz and Dats'in (Ethiopia)]. Complutum 28(2), 445-60.

Hernando, A., 2020. Subordinación de género entre los Gumuz y Dats'in de Etiopía. Matrimonio, cuerpo y cultura material [Gender subordination among the Gumuz and Dats'in of Ethiopia. Marriage, body and material culture], in Cultura material e Historia de las mujeres [Material culture and women's history], eds A. Muñoz Fernández \& M. del Moral Vargas. Granada: Comares, 3-39.

Hershatter, G., 1993. The subaltern talks back: reflections on subaltern theory and Chinese history. Positions 1, 103-30.

hooks, b., A. Brah, C. Sandoval, et al., 2004. Otras Inapropiables. Feminismos Desde Las Fronteras [Inappropriate others. Feminisms from the borders]. Madrid: Traficantes de Sueños.

James, W., 1979. 'Kwanim Pa. The making of the Uduk people. An ethnographic study of survival in the Sudan-Ethiopian borderlands. Oxford: Clarendon Press. 
James, W., 1988. Perceptions from an African slaving frontier, in Slavery and Other Forms of Unfree Labour, ed. L. J. Archer. London: Routledge, 130-41.

James, W., 2016. Charles Jedrej and the 'deep rurals': a West African model moves to the Sudan, Ethiopia, and beyond. Critical African Studies 8(1), 32-46.

Jedrej, M.C., 2006. Were Nuba and Hadjeray stateless societies? Ethnohistorical problems in the Eastern Sudan region of Africa. Mitteilungen zur Kulturkunde 52, 205-25.

Kidanemariam Demellew, 1987. The Shanqella of Metekel: Some Tentative Notes. Unpublished BA dissertation, Addis Ababa University.

Kistler, E. \& M. Mohr, 2016. The Archaic Monte Iato: between coloniality and locality, in Materielle Kultur und Identität im Spannungsfeld zwischen Mediterraner Welt und Mitteleuropa/Material Culture and Identity between the Mediterranean World and Central Europe, ed. H. Baitinger. (Tagungen Band 27.) Mainz: Römisch-Germanischen Zentralmuseum, 81-98.

Larsen, N., 2001. Determinations: Essays on theory, narrative and nation in the Americas. London: Verso.

Lázaro Ávila, C., 1994. Los cautivos en la frontera araucana [Captives on the Araucanian frontier]. Revista Española de Antropología Americana 24, 191-207.

León, L., 1991. Maloqueros y conchavadores en Araucanía y las Pampas, 1700-1800 [Maloqueros and conchavadores in Araucania and the Pampas, 1700-1800]. Temuco: Universidad de La Frontera.

Liebmann, M., 2012. Revolt. An archaeological history of pueblo resistance and revitalization in 17th century New Mexico. Tucson (AZ): University of Arizona Press.

Liebmann, M. \& M.S. Murphy (eds), 2010. Enduring Conquests: Rethinking the archaeology of resistance to Spanish colonialism in the Americas. Santa Fe (NM): School of Advanced Research Press.

Lightfoot, K.G., 2015. Dynamics of change in multiethnic societies: an archaeological perspective from colonial North America. PNAS 112(30), 9216-23.

Liguori, G., 2005. "Senso Comune»e «Buon Senso» nei Quaderni del Carcere ['Common sense' and 'good sense' in the Prison Notebooks]. Report for the conference on the vocabulary of the Quaderni of IGS Italia, Rome, 13 May.

Malkin, I., 2002. A colonial middle ground: Greek, Etruscan and local elites in the Bay of Naples, in The Archaeology of Colonialism, eds C.L. Lyons \& J. K. Papadopoulos. Los Angeles (CA): Getty Research Institute, 151-81.

Mani, L., 1998. Contentious Traditions: The debate on sati in colonial India. Berkeley/Los Angeles: University of California Press.

Marín-Aguilera, B., L. Adán Alfaro \& S. Urbina Araya, 2019. Challenging colonial discourses: the Spanish imperial borderland in Chile (16th-19th centuries), in Transnational Perspectives on the Conquest and Colonization of Latin America, eds J. Mander,
D. Mindgley \& C.D. Beaule. New York (NY): Routledge, 85-98.

McGuire, R.H., 2006. Marxism and capitalism in historical archaeology, in The Cambridge Companion to Historical Archaeology, eds D. Hicks \& M.C. Beaudry. Cambridge: Cambridge University Press, 123-42.

Mohanty, C.T., 1991. Under Western eyes: feminist scholarship and colonial discourses, in Third World Women and the Politics of Feminism, eds C.T. Mohanty, A. Russo \& L. Torres. Bloomington (IN): Indiana University Press, 51-80.

Negash, M., 2017. Cursed no more - women in western Ethiopia reject childbirth alone in the bush. United Nations Population Fund News. https://www.unfpa. org/news/cursed-no-more-women-western-ethiopiareject-childbirth-alone-bush

Nilsen, A.G. \& S. Roy, 2015. Introduction. Reconceptualizing subaltern politics in contemporary India, in New Subaltern Politics: Reconceptualizing hegemony and resistance in contemporary India, eds A.G. Nilsen \& S. Roy. New Delhi: Oxford University Press, 1-26.

Ocampo, C., C.R. Mera \& D. Munita, 2005. Antecedentes arqueológicos prehispánicos para la ruka mapuche: el sitio 'Km 0 - Enlace Temuco' [Pre-Hispanic archaeological antecedents for the Mapuche ruka: The site ' $\mathrm{Km}$ 0 - Enlace Temuco'], in Actas del XVI Congreso Nacional de Arqueología Chilena [Proceedings of the 16th National Congress of Chilean Archaeology], ed. M. M. Massone. Concepción: Museo de Historia Natural de Concepción, 193-202.

Orser, C.E. \& P.P.A. Funari, 2001. Archaeology and slave resistance and rebellion. World Archaeology 33(1), 61-72.

Pankhurst, R., 1990. A Social History of Ethiopia: The northern and central Highlands from Early Medieval times to the rise of Emperor Téwodros II. Addis Ababa: Institute of Ethiopian Studies.

Pankhurst, R., 1997. The Ethiopian Borderlands: Essays in regional history from ancient times to the end of the 18th century. Lawrenceville (NJ): Red Sea Press.

Parentini, L.C., 1999. ¿Delincuencia o malones? La justicia no comprendida [Criminals or malones? Justice misunderstood]. Revista de Humanidades 5, 127-38.

Parry, B., 2004. Postcolonial Studies: A materialist critique. London/New York: Routledge.

Patterson, O., 1982. Slavery and Social Death: A comparative study. Cambridge (MA): Harvard University Press.

Pollock, S. \& R. Bernbeck, 2016. The limits of experience: suffering, Nazi forced labor camps, and archaeology, Archaeological Papers of the American Anthropological Association 27(1), 22-39.

Prakash, G., 1994. Subaltern studies as postcolonial criticism. American Historical Review 99(5), 1475-90.

Quiroz, D. \& F. Fuentes-Mucherl, 2012. De huesos y carne de ballena: el uso de los restos de cetáceos en las costas de la Araucanía [On whale bones and flesh: The use of cetacean remains on the Araucanian coasts], in Actas Del XVIII Congreso Nacional de 
Arqueología Chilena [Proceedings of the 18th National Congress of Chilean Archaeology], eds C. Becker \& M. Uribe. Valparaíso: Sociedad Chilena de Arqueología, 481-86.

Quiroz, D. \& M. Sánchez (eds), 1997. La Isla de Las Palabras Rotas [The island of broken words]. Santiago de Chile: Dirección de Bibliotecas, Archivos y Museos.

Rappaport, J., 2014. The Disappearing Mestizo: Configuring difference in the colonial New Kingdom of Granada. Durham (NC): Duke University Press.

Retamal Ávila, J., 2000. Testamentos de 'Indios' en Chile colonial: 1564-1801 ['Indian' last wills in colonial Chile: 1564-1801]. Santiago de Chile: Universidad Andrés Bello.

Routledge, B., 2014. Archaeology and State Theory: Subjects and objects of power. London: Bloomsbury.

Said, E.W., 1989. Representing the colonized: anthropology's interlocutors. Critical Inquiry 15(2), 205-25.

Sater, W.F., 1974. The Black experience in Chile, in Slavery and Race Relations in Latin America, ed. R.B. Toplin. Westport (CT): Greenwood Press, 13-50.

Sauer, J.J., 2015. The Archaeology and Ethnohistory of Araucanian Resilience. Cham: Springer.

Scott, J.C., 1985. Weapons of the Weak: Everyday forms of peasant resistance. New Haven (CT): Yale University Press.

Scott, J.C., 1990. Domination and the Arts of Resistance: Hidden transcripts. New Haven (CT): Yale University Press.

Scott, J.C., 2013. Decoding Subaltern Politics: Ideology, disguise, and resistance in Agrarian politics. Abingdon: Routledge.

Sharpe, J. \& G.C. Spivak, 2003. A conversation with Gayatri Chakravorty Spivak: politics and the imagination. Signs 28(2), 609-24.

Singleton, T.A. (ed.), 2009. The Archaeology of Slavery and Plantation Life. Walnut Creek (CA): Left Coast Press.

Spencer-Wood, S., 2010. Gendered power dynamics between religious sects, ethnic groups and classes in Jewish communities on Boston's landscape, 1840-1936, in The Archaeology and Preservation of Gendered Landscapes, eds S.B. Baugher \& S. Spencer-Wood. New York (NY): Springer, 198-232.

Spencer-Wood, S.M., 1994. Diversity and nineteenth century domestic reform: relationships among classes and ethnic groups, in Those of Little Note: Gender, race and class in historical archaeology, ed. E.M. Scott. Tucson (AZ): University of Arizona Press.

Spivak, G.C., 1988. Can the subaltern speak?, in Marxism and the Interpretation of Culture, eds C. Nelson \& L. Grossberg. Urbana (IL): University of Illinois Press, 271-313.

Spivak, G.C., 1990. The Post-Colonial Critic. Interviews, strategies, dialogues. New York (NY): Routledge.

Spivak, G.C., 2005. Scattered speculations on the subaltern and the popular. Postcolonial Studies 8(4), 475-86.

Taddesse Tamrat, 1982. Early Trends of Feudal Superimposition on Gumuz society in Western Gojjam. Addis Ababa: Institute of Ethiopian Studies.
Taddesse Tamrat, 1988. Nilo-Saharan interactions with neighbouring highlanders: the case of the Gumuz of Gojjam and Wallaga, in Proceedings of the Workshop on Famine Experience and Resettlement in Ethiopia. December 29-30, 1988. Addis Ababa: Addis Ababa University, Institute of Development Research, 7-21.

Tarble de Scaramelli, K., 2012. Effects of empire: gendered transformations on the Orinoco frontier, in The Archaeology of Colonialism: Intimate encounters and sexual effects, eds B.L. Voss \& E.C. Casella. Cambridge: Cambridge University Press, 138-55.

Valenzuela, J., 2009. Esclavos mapuches. Para una historia del secuestro y deportación de indígenas en la Colonia [Mapuche slaves. A history of the kidnapping and deportation of indigenous people in the Colony], in Historias de Racismo y Discriminación En Chile. Una Mirada Interdisciplinaria [Racism and discrimination stories in Chile. An interdisciplinary approach], eds R. Gaune \& M. Lara. Santiago: Uqbar Editores, 225-60.

van Dommelen, P., 2006. Colonial matters. Material culture and postcolonial theory in colonial situations, in Handbook of Material Culture, eds C. Tilley, W. Keane, S. Küchler, M. Rowlands \& P. Spyer. London: Sage, 104-24.

van Dommelen, P., 2014. Subaltern archaeologies, in Rethinking Colonial Pasts through Archaeology, eds N. Ferris, R. Harrison \& M.V. Wilcox. Oxford: Oxford University Press, 469-75.

Walker, T.J., 2017. Exquisite Slaves: Race, clothing and status in colonial Lima. Cambridge: Cambridge University Press.

Ware, R.T., III, 2011. Slavery in Islamic Africa, 1400-1800, in The Cambridge World History of Slavery, eds D. Eltis \& S.L. Engerman. Cambridge: Cambridge University Press, 47-80.

Zapater, H., 1978. Aborígenes Chilenos a Través de Cronistas y Viajeros [Chilean aborigines through chroniclers and travellers]. Santiago de Chile: Andrés Bello.

Zeleke, M., 2010. The Mother and the Bread Winner: The socioeconomic role and status of Gumuz women. Berlin: Lit.

Zuchtriegel, G., 2018. Colonization and Subalternity in Classical Greece: Experience of the nonelite population. Cambridge: Cambridge University Press.

\section{Author biography}

Beatriz Marin-Aguilera is a Renfrew Fellow at the McDonald Institute for Archaeological Research at the University of Cambridge (UK). Her current research focuses on the archaeology of colonialism and frontiers from comparative perspectives in Chile, Ethiopia and the western Mediterranean, with a particular emphasis on the subaltern experience. She has published articles in Antiquity, World Archaeology, the Journal of Mediterranean Archaeology, Complutum and Archaeologies. 